\title{
PARENT'S PERSPECTIVES OF SCHOOL-AGE ANXIETY RESPONSES GET IV INSTALLATION
}

\author{
Indira Mastura Pulungan, Nur Asnah Sitohang \\ Universitas Sumatera Utara \\ sitohangnurasnah@gmail.com
}

\begin{abstract}
The IV installation procedure is an invasive procedure that children fear because of the use of needles. The IV procedure can cause anxiety for the child. Children's anxiety is indicated by worry, anxiety, and physical complaints. This study aims to determine how child's anxiety responds to get IV installation based on the parents' perspectives. This research method is a cross-sectional descriptive study. The sampling technique in this study was total sampling with 69 respondents. Respondents in this study were parents who had school-age children with IV installation experience for a maximum of the last 2 years. The questionnaire was given via Google Form because of the research period on coronavirus pandemic. The results showed that the majority of school-age children showed a response with fear in $71 \%$, closed their eyes in $67 \%$, and showed a tense and pale facial expression when the IV installation was inserted in 67\%. School-age children require the presence of parents in dealing with hospital procedures, especially IV installation. School-age children also need an explanation regarding the procedures given. The children will feel calmer when they know how the procedure is given.
\end{abstract}

Keywords: Anxiety Responses, IV installation, School-age children

Received 2 February 2021 Accepted 23 July 2021

\section{INTRODUCTION}

School-age children are at the stage to be able to think logically but still have to develop skills in the thinking process. The phase of school-age children already has a great curiosity about something by doing exploration and being able to show creativity. The school-age stage is also able to perceive pain based on one's own experience and that of others so that children's pain will depend on the child's coping[1]. Being able to socialize with school friends and getting information is the reason children are able to perceive illness.

School-age children are still vulnerable to various diseases and even require hospitalization in various health services, especially in hospitals[2]. Based on RISKESDAS data in 2018,children in Indonesiaget 28,125,485. In the National Socio-Economic Survey (SUSENAS) in 2017, there were $10,940,813$ children experiencing health complaints who were hospitalized in both government and private hospitals. North Sumatera Province has 206,781 children undergoing hospitalization with 85,752 children of whom are hospitalized. Children who undergo inpatient care in various health services require children to be given IV installation[3,4].

IV installation is an action taken to provide fluids in the form of drugs or vitamins to patients who experience severe fluid or nutritional disorders. IV installation of fluids is given for a long time and is carried out by inserting a device into the vein including the cephalic vein, femoral vein, and temporalis vein. This procedure can cause discomfort and anxiety before taking action, especially for children who will be hospitalized [5].

Anxiety is a person's response in facing a scary thing and is indicated by worry, anxiety, and even causing physical complaints[6]. Anxiety arises because of the feeling of pressure and fear of having an IV inserted accompanied by experiences from oneself and those around 
you. This experience led to the child's perception that the intravenous operation was a scary thing to do[7].

The response of children's anxiety to actions while in hospital is influenced by several factors such as age, experience, support from their parents, and coping. The anxiety response caused to children is also different, such as verbalizing, yelling, aggressively taking action, and being uncooperative when performing procedures[1].

Research the study and literature conducted on web pages such as PubMed, Science Direct, Research Gate, Ebsco, Google Scholar, and Pediatric Nursing in 2020 have conducted a lot of research related to anxiety responses associated with other conditions or variables. Research that has been investigated did not explain in detail the response to the anxiety of school-age children at IV insertion. This condition made researchers want to conduct research related to the anxiety response of school-age children get IV installation based on the parents' perspective.

\section{RESEARCH METHODS}

This research method is a descriptive study with a cross-sectional approach. This research was conducted by measuring and assessing the anxiety response at one time. The sampling technique used the total sampling method. The samples obtained after distributing questionnaires were for 69 respondents. This research was conducted in Medan using Google Form for filled the questionnaire. Using Google from media because this research due in the Covid-19 pandemic situation.

The data in this study were analyzed by presenting the frequency distribution with univariate analysis carried out by analyzing the anxiety of school-age children gets IV installation. The data are in the form of the current child's age, the age of the children who get IV installation last time, gender, religion, ethnicity, the experience of being hospitalized and being given intravenous procedures, and anxiety responses. The research data were analyzed by a univariate form of a frequency distribution. Data analysis was carried out by finding the total score of the respondent's answer and adjusting it to the anxiety response shown by the child during getting IV installation.

\section{FINDINGS AND DISCUSSION}

The results of this study provide an overview and description of the anxiety response of school-age children get IV installation is placed based on the perceptions of the parents. The results of this study will also be described on the characteristics of school-age children, namely based on gender, the child's experience, and the last age get IV installation. All respondents in this study were parents who had children already get IV installation at schoolage with a maximum period of the last 2 years.

The results of the respondent's characteristicfound that the majority of children were male, as many as $62 \%$ of the children, the majority of the children were at the age of 6 years, $33 \%$ of the respondents, with experience of IV installation, the majority experienced by children who get IV installation first time in $48 \%$ respondents.

School-age children will not say if they feel scared, but it will be reflected in the facial expressions shown by the child. Children will need parents even if they don't ask for it. This statement is following the results of research which shows that the majority of children feel afraid as much as $71 \%$, show a tense and pale face $67 \%$, and close their eyes as much as $67 \%$.

School-age children can relate information that has been previously received from the experiences of others with the conditions they are going to face [8]. Children feel afraid according to the use of needles during IV installation so that children feel afraid to do the IV installation. The information that has been received is a factor that makes children experience fear during the IV installation $[9,14]$. 
Table1. Frequency Distributionand Data Percentage of Respondent's Characteristic $(n=69)$

\begin{tabular}{ccc}
\hline \multicolumn{1}{c}{ Respondent's Characteristic } & Frequency (f) & Percentage (\%) \\
\hline Religion & $\mathbf{6 9}$ & $\mathbf{1 0 0}$ \\
\hline Islam & 53 & 77 \\
Christian Protestant & 8 & 12 \\
Chatolic & 8 & 12 \\
\hline Gender of Children & $\mathbf{6 9}$ & $\mathbf{1 0 0}$ \\
\hline Boy & 43 & 62 \\
Girl & 26 & 38 \\
\hline Ethnicity & $\mathbf{6 9}$ & $\mathbf{1 0 0}$ \\
\hline Batak & 34 & 49 \\
Jawa & 22 & 32 \\
Malay & 4 & 6 \\
Minang & 4 & 6 \\
Sunda & 2 & 3 \\
Manado & 1 & 1 \\
Arab & 2 & 3 \\
\hline Age of the childrenget IV installation last time & $\mathbf{6 9}$ & $\mathbf{1 0 0}$ \\
\hline 6 years old & 23 & 33 \\
7 years old & 3 & 4 \\
8 years old & 14 & 20 \\
9 years old & 7 & 10 \\
10 years old & 13 & 19 \\
11 years old & 2 & 3 \\
12 years old & 7 & 10 \\
\hline Experiences get intravenous procedure & $\mathbf{6 9}$ & $\mathbf{1 0 0}$ \\
\hline 1 times & 33 & 48 \\
2 times & 17 & 25 \\
3 times & 14 & 20 \\
5 times & 5 & 7 \\
\hline Illness & $\mathbf{6 9}$ & $\mathbf{1 0 0}$ \\
\hline Fever & 25 & 36 \\
Typhoid & 17 & 25 \\
Diarrhea & 14 & 20 \\
Dengue Fever & 6 & 9 \\
Nauseous vomit & 2 & 3 \\
Bone surgery & 1 & 1 \\
Appendicitis & 2 & 3 \\
Headache & 1 & 1 \\
Fracture & & \\
\hline
\end{tabular}

Handayani \& Daulima (2020) also said the school-age children will feel more comfortable by hugging their parents tightly. Hugging can reduce the anxiety and pain your child feels. Respondents in the study said that children felt more comfortable when their parents were beside them when they were going to do invasive procedures including IV installations[8].

Research that has been conducted shows that as many as $58 \%$ of children hold their parents' hands tightly and the children hug their parents tightly. Children hug their parents because they need parental assistance during the invasive procedure. Parents will try to make the child keep calm during the IV insertion such as giving soothing words, touching, and hugs [8,10-12].

Parents have an advantage when accompanying children during invasive procedures such as IV installations. Parents in their research stated that they felt calmer and more comfortable when they were able to accompany their child during IV installation. Parents can guarantee the condition of their children when they see firsthand the procedures performed on their children[12]. 
Table 2. Distribution of Frequency and Percentage of Children's Anxiety Responses getIV installation Based on Parent's Perspectives in Medan $(n=69)$

\begin{tabular}{clcc}
\hline No & \multicolumn{1}{c}{ Children's Anxiety Response getIV installation } & Yes (\%) & No (\%) \\
\hline 1 & The child holds my hand tightly before getting IV installation & 58 & 42 \\
2 & The child cries when getting IV installation & 49 & 51 \\
3 & The child sweats easily & 51 & 49 \\
4 & The child asks the nurse to leave the room & 26 & 74 \\
5 & The child said that he did not want to have an IV installation & 52 & 48 \\
6 & The child persuades parents to go home & 55 & 45 \\
7 & The child kicks the nurse & 12 & 88 \\
8 & I felt the child's body and fingers tremble & 45 & 55 \\
9 & The child screams & 39 & 61 \\
10 & The child shook off the nurse's hand who was holding it & 28 & 72 \\
11 & The child tries to remove the IV tube & 20 & 80 \\
12 & The child hugs the parents tightly & 58 & 42 \\
13 & The child pulls the body part to get infused & 36 & 64 \\
14 & The child has a tense facial expression and a pale face when getting IV & 67 & 33 \\
& installation & & \\
15 & The child closed his/her eyes & 67 & 33 \\
16 & The child feels scared & 71 & 29 \\
\hline
\end{tabular}

Boys show more courage than girls. Girls will show their fear by crying. Boys' courage is due to the cultural factor that boys should be braver and stronger than girls. The results showed that the majority of the response to crying was shown by girls as much as $56 \%$ than girls, namely as much as $45 \%$ [13].

Qualitatively research was carried out and children were asked to describe the feelings experienced during hospitalization. The results showed that school-age children aged 8 and 9 at hospitalization described responses with fear, sadness, and anger. The research conducted showed that all school-age children aged 9 years showed responses with stiff faces and fear. School-age children at the age of 8 showed a majority response, namely holding their parents' hand tightly (71\%) and inviting parents to go home (71\%)[14].

Children hold their parents' hands because they are afraid and worried that the procedure given will have a bad impact on them. Nurses in this condition must explain in advance to the child the purpose of the procedure being given, how the procedure is given, and the severity of the pain that will be felt[15]. Kline, et al., (2018) stated that if children in 6-12 years oldduring cognitive development, children have started to think rationally and know the causes of pain. Children will also relate the experiences of others to what they will feel[16].

The majority of children aged 10 years showed a response by closing their eyes as much as $62 \%$, easily sweating as much as $54 \%$, and did not want to be infused as much as $46 \%$. This condition is because children at this age have learned how to deal with pain or discomfort. In generally, 10-year-olds showed a response by closing their eyes, clenching their fists, or by grimacing[14].

A child will be said that he did not want to have an IV installation because this procedure was the most concerned about school-age children while being hospitalized in the hospital. Handayani \& Daulima's research (2020) states that in their research, children aged 9-11 years feel that infusion is the least preferred procedure during hospitalization. The child will also feel angry and cry when the nurse takes this action[8].

Handayani \& Daulima's research (2020) states that 11 -year-olds feel less anxious if they can hug and hold their parents during the infusion. Research that has been conducted shows that school-age children with 2 respondents aged 11 years show a response by closing their eyes, holding their parents' hands, and hugging them tightly. This statement shows that children need their parents when the child is going to undergo a procedure that is deemed scary. School-age children will not say if they need their parents or immediate family, but they will need parents when they undergo hospitalization and hospital procedures [8].

Children's experiencewithIV installation in this study is related to anxiety responses such 
as fear and pale face. This response has decreased if the child is getting infusions more frequently[17]. Seventy-nine percent of children with a single intravenous experience showed a fear response and as many as $76 \%$ of children showed a pale face. $76 \%$ of children with experience of two infusions showed a fear response and $71 \%$ of children showed a pale face. For children with three times experience, $64 \%$ of children showed a response with fear and $57 \%$ of children showed a response with a pale face. Only $20 \%$ of children with five times the experience of infusions showed a fear response and stiff faces.

Children who have their first experience while undergoing procedures in the hospital will experience greater fear and anxiety than children who have experience. The child feels frightened because the hospital is a strange environment for the child. The child also feels scared and shows a pale face because the child is afraid of using needle procedures such as intravenous lines[18].

\section{CONCLUSION}

The results of the research conducted proved that the majority of school-age children showed a response to fear in $71 \%$, closed their eyes $67 \%$ and showed a tense and stiff facial expression $67 \%$. The results of the research conducted also indicated that the factors that could influence the child's response to infusion were age and gender. Experience at infusion in this study cannot be used as a determining factor in the response of school-age children to infusion.

\section{REFERENCES}

[1] M. J. Hockenberry and D. Wilson, Wong's nursing care of infants and children, 10th ed. Canada: Elsevier Ltd, 2016.

[2] N. Sumarni, Y. Yuliana, and Y. R. Sari, 'HUBUNGAN KEHADIRAN ORANG TUA DENGAN KECEMASAN ANAK SAAT PEMBERIAN OBAT IV LINE DI RSU GARUT', Jurnal Dunia Kesmas, vol. 7, no. 3, pp. 146-155, 2018.

[3] Kesehatan Kemenkes RI, 'Data dan Informasi Profil Kesehatan Indonesia 2019', Kementrian Kesehatan RI, Jakarta, 2020.

[4] Subdirektorat Statistik Rumah Tangga, 'Statistik Kesejahteraan Rakyat', Jakarta, 2019.

[5] Nurmi, 'Analisis Kecemasan Orang Tua dan Anak Dalam Pemasangan Infus pada Anak Balita di RSUD Syekh Yusuf Kab. Gowa', 2016.

[6] D. Wulandari and Fitriana, 'Komunikasi Terapeutik Perawat Dengan Tingkat Kecemasan Anak Usia Prasekolah (3-5 Tahun) Selama Pemasangan Infus', Jornal of nursing and public health, vol. 5, no. 2, pp. 19-24, 2017.

[7] I. T. Suminar, I. L. Gamayanti, and L. Lusmilasari, 'Relationship Between Nurse Supports and Fears of Hospitalized School Age Children in Pku Muhammadiyah Hospital, Yogyakarta, Indonesia', Belitung Nursing Journal, vol. 3, no. 4, pp. 376-382, 2017, doi: 10.33546/bnj.111.

[8] A. Handayani and N. H. C. Daulima, 'Parental presence in the implementation of atraumatic care during children's hospitalization', Pediatric Reports, vol. 12, pp. 11-14, 2020, doi: 10.4081/pr.2020.8693.

[9] A. M. McCarthy, C. Kleiber, K. Hanrahan, M. B. Zimmerman, N. Westhus, and S. Allen, 'Factors Explaining Children's Responses to Intravenous Needle Insertions', Bone, vol. 59, no. 6, pp. 407-416, 2010, doi: 10.1038/jid.2014.371.

[10] D. S. Sağlık and S. Çağlar, 'The Effect of Parental Presence on Pain and Anxiety Levels During Invasive Procedures in the Pediatric Emergency Department', Journal of Emergency Nursing, vol. 45, no. 3, pp. 278-285, 2019, doi: 10.1016/j.jen.2018.07.003.

[11] M. Zannah, R. Agustina, and E. Marlinda, 'Peran Orangtua terhadap Tingkat Kecemasan Anak Pada Saat Pemasangan Infus Diinstalasi Gawat Darurat (IGD) RSUD Banjarbaru', vol. 3, no. 2, pp. 26-33, 2015. 
[12] T. Orenius, LicPsych, H. Säilä, K. Mikola, and L. Ristolainen, 'Fear of Injections and Needle Phobia Among Children and Adolescents: An Overview of Psychological, Behavioral, and Contextual Factors', SAGE Open Nursing, vol. 4, pp. 1-8, Jan. 2018, doi: $10.1177 / 2377960818759442$.

[13] K. Bsiri-Moghaddam, M. Basiri-Moghaddam, L. Sadeghmoghaddam, and F. Ahmadi, 'The concept of hospitalization of children from the view point of parents and children', Iranian Journal of Pediatrics, vol. 21, no. 2, pp. 201-208, 2011.

[14] M. J. Hockenberry, D. Wilson, and C. C. Rodgers, Wong's Essentials of Pediatric Nursing, 10th ed. Canada: Elsevier, 2014.

[15] M. Afriani and S. I. Rahayuningsih, 'CHILDREN REACTION TOWARDS STRESSOR HOSPITALIZATION WITH ANXIETY LEVEL IN CHILDREN IN SCHOOL AGE IN GENERAL HOSPITAL DR. ZAINOEL ABIDIN', Jurnal Ilmiah Mahasiswa Fakultas Keperawatan, vol. 1, no. 1, pp. 1-8, 2016.

[16] M. W. Kline et al., Rudolph's Pediatrics, 23rd ed. Texas: Mc Graw Hill, 2018.

[17] H. Herman, D. Novrianda, and M. A. P. Putri, 'Pengaruh Intervensi Pelibatan Keluarga Terhadap Kecemasan Anak yang Mengalami Hospitalisasi di Ruang Perawatan Anak RSUD dr. Rasidin Padang Tahun 2016', NERS Jurnal Keperawatan, vol. 13, no. 2, p. 78, 2018, doi: 10.25077/njk.13.2.78-85.2017.

[18] Hermalinda, D. Novrianda, and M. A. P. Putri, 'Pengaruh Intervensi Pelibatan Keluarga Terhadap Kecemasan Anak yang Mengalami Hospitalisasi di Ruang Perawatan Anak RSUD dr. Rasidin Padang Tahun 2016', NERS Jurnal Keperawatan, vol. 13, no. 2, pp. 78-85, 2017, doi: 10.25077/njk.13.2.78-85.2017. 